\title{
In-vivo Mice Pre-Implantation Embryo Development after Oral Administration Ethanolic Extract of Cogon Grass Roots (Imperata cylindrica L)
}

\author{
(PERKEMBANGAN EMBRIO PREIMPLANTASI SECARA IN VIVO \\ SETELAH PEMBERIAN EKSTRAK ETHANOL AKAR \\ ALANG-ALANG (IMPERATA CYLINDRICA L) PER ORAL) \\ Jaqueline Sudiman ${ }^{1}$, Madeline Priscilla ${ }^{2}$, Alkaustariyah Lubis ${ }^{2}$, \\ Mas Rizky Anggun Adipurna Syamsunarno ${ }^{3}$, \\ Sony Heru Sumarsono ${ }^{4}$, Rini Widyastuti ${ }^{5}$ \\ ${ }^{1}$ Department of Anatomy, Faculty of Medicine, Universitas Udayana, \\ Jl. Sudirman, Denpasar, Bali, Indonesia, 80234 \\ ${ }^{2}$ Study Program of Undergraduate Medicine, \\ Faculty of Medicine, Universitas Padjadjaran, Sumedang, Indonesia, 45363 \\ ${ }^{3}$ Department of Biomedical Sciences, \\ Faculty of Medicine, Universitas Padjadjaran, \\ Hegarmanah, Jatinangor, Sumedang, Indonesia, 45363 \\ ${ }^{4}$ Physiology, Developmental Biology, \\ and Biomedical Science Research Group, \\ School of Life Science and Technology, \\ Bandung Institute of Techogy, Bandung, West Java, Indonesia, 40116 \\ ${ }^{5}$ Laboratory of Animal Reproduction and Artificial Insemination, \\ Departement of Animal Production, Animal Husbandry Faculty, \\ Universitas Padjadjaran, Jatinangor, Sumedang, Indonesia, 45363 \\ Office Phone: +6222 7798241; Email: r.widyastuti@unpad.ac.id
}

\begin{abstract}
Cogon grass (Imperata cylindrica L) is known as a medicinal plant that is scattered almost worldwide. Despite its role that inhibits another plant's growth, cogon grass possesses several benefits in health. This research has to identify the effect of short-term gavage ethanolic extract of cogon grass roots (CGG) to in-vivo mice preimplantation embryo development. A total of 60 female mice were divided into control and treatment groups, dosages at 90 and $115 \mathrm{mg} / \mathrm{kg}$ of body weight of CGG, orally gavage for 20 days. The superovulation of mice was done at the end of the CGG treatment by injecting 5 IU Pregnant Mare Serum Gonadotropin (PMSG) and after 48 hours, followed by 5 IU Human Chorionic Gonadotropin (hCG) injection and directly the mice were mated. The mating rate was checked by the appearance of the vaginal plug 12 hours after hCG injection. Mice were sacrificed, the oviducts and cornua of uteri were isolated to collect the oocytes and embryonic cells by flushing the oviducts and cornua uteri with Phosphate-buffered saline (PBS). The effects of CGG as an antifertility were evaluated by measuring the number of oocytes, fertilization, and in-vitro embryo development rates. The results showed significantly reduced about half of the mating rate in the $115 \mathrm{mg} / \mathrm{kg}$ BW group $(\mathrm{p}<0.05)$ compared to control. However, the $90 \mathrm{mg} / \mathrm{kg} \mathrm{BW}$ dose reduced $20 \%$ mating rate compared to control, and not significant ( $\mathrm{p}>0.05)$. In all treatment groups, only half oocytes fertilized. The cleavage and blastocyst rate in $115 \mathrm{mg} / \mathrm{kg} \mathrm{BW}$ group were significantly lower compared to the control group $(\mathrm{p}<0.05)$. In conclusion, oral gavage of cogon grass root ethanolic extract disrupts the mating process and development of in-vivo mice preimplantation embryo development.
\end{abstract}

Keywords: Imperata cylindrical L; mating rates; preimplantation development of the embryos; antifertility agent 


\begin{abstract}
ABSTRAK
Alang-alang (Imperata cylindrica L) dikenal sebagai gulma dan telah dimanfaatkan oleh masyarakat sebagai tanaman obat. Penelitian ini bertujuan untuk mengetahui efek jangka pendek pemberian ekstrak akar alang-alang terhadap perkembangan implantasi embrio. Mencit betina sebanyak 60 ekor dibagi menjadi tiga kelompok yaitu kontrol (aquadest), dosis $90 \mathrm{mg} / \mathrm{kgBB}$, dan $115 \mathrm{mg} / \mathrm{kgBB}$ yang diberikan selama 20 hari. Superovulasi dilakukan dengan menyuntikkan 5 IU Pregnant Mare Serum Gonadotropin (PMSG) dilanjutkan 48 jam kemudian dengan injeksi 5 IU Human Chorionic Gonadotropin (hCG). Mencit segera dikawinkan lalu diperiksa keberadaan sumbat vagina setelah 12 jam untuk menentukan persentase keberhasilan kawin. Mencit dikorbankan nyawanya untuk isolasi oosit dan embrio yang diambil dari oviduk pada 14 jam pascainjeksi hCG untuk menghitung persentase jumlah oosit, oosit yang mengalami fertilisasi, dan 24 jam pasca hCG kornua uteri di bersihkan (flushing) dengan menggunakan Phosphatebuffered saline (PBS) untuk mendapatkan oosit dan embrio. Evaluasi dilakukan dengan melihat jumlah oosit, jumlah oosit yang terbuahi, jumlah embrio yang berkembang hingga blastosit. Pada dosis $115 \mathrm{mg} /$ kgBB jumlah mencit yang melakukan perkawinan hanya setengah apabila dibandingkan dengan kelompok kontrol $(\mathrm{p}<0.05)$. Secara umum, terjadi penurunan perkembangan embrio secara in vivo pada kelompok perlakuan. Pada dosis $115 \mathrm{mg} / \mathrm{kgBB}$, penurunan yang terjadi cukup signifikan dibandingkan dengan kontrol ( $<<0.05$ ), sedangkan pada dosis $90 \mathrm{mg} / \mathrm{kgBB}$ terjadi penurunan sebesar $20 \%$ dan tidak signifikan $(p>0.05)$. Sebagai simpulan, pemberian ekstrak akar alang-alang pada mencit menurunkan laju perkawinan dan perkembangan embrio pre implantasi.
\end{abstract}

Kata-kata kunci: Imperata cylindrica L; laju kawin, perkembangan embrio praimplantasi, agen antifertilitas

\section{INTRODUCTION}

Currently available data in 2017 indicate at least 206 million pregnancies recorded in developing regions, which $43 \%$ are unintended pregnancies, and about $84 \%$ of all unintended pregnancies in developing regions have an unmet need for effective contraception (Karra, 2016). The solution of family planning program to prevent population boom in the world by modern contraceptives have been implemented with aimed to prevent future unwanted pregnancy and as birth control by limiting the space between children (Hull and Mosley, 2009). Oral contraceptives are the most artificial contraception selected because the price is cheaper than other contraceptive methods and available in the market, but it has limited success or side effects (Agarwal and Allan, 2010). Synthetic oral contraceptives have many side effects such as nausea, dizziness, headaches, stomachaches, vomit, and severe side effects such as breast cancer, cervical cancer, thrombosis, direct impact on the brain and infertility in rare case (Shukla and Jamwal, 2017). Current safe and minimal side effect contraception are urgently needed.

Previous studies have been done to investigate herbal medicine originated from plants with natural ingredients for fertility (Agarwal and Allan, 2010). Some herbal contraceptions have been investigated, but they are less potent than the synthetics. For instance, Azadirachta indica (Neem), Labisia pumila (Fatima grass), Mentha pulegium (pennyroyal), Plumbago rosea (leadwort), Hibiscus rosasinensis (chinese hibiscus), Trichosanthes cucumerina (snake gourd), Curcuma longa (turmeric) exhibit anovulatory, antiestrogenic, antiimplantantation, and antifertility by modifying hormonal balance lead to disturbance normal menstrual cycle follicle growth (Bala 2014, Shweta et al., 2011).

In our previous study, ethanolic extract of cogon grass roots has the ability increase secondary sperm abnormal morphology (Widyastuti et al., 2018), decrease sperm concentration (Lubis et al., 2018) prolonge diestrus phase (Robianto et al., 2019), induced disruption on testis interstitial area and seminiferous tubule (Widyastuti et al., 2020) and disrupt folliculogenesis in mice (Widyastuti et al., 2020). However, there is a lack of information about the effect of ethanolic extract of $I$. cylindrica roots to in-vivo mice embryo development. This research has aimed to examine the effects of short-term gavage of ethanolic extract of cogon grass roots in mice mating rate, the number of ovulated mice oocytes and the development of in-vivo mice preimplantation embryo. 


\section{RESEARCH METHODS}

\section{Preparation of Plant Extract}

Cogon grass roots were purchased from Solo, Central Java, Indonesia. Cogon grass roots were macerated by ethanol $95 \%$ for 72 hours, filtrated with a vacuum filter, and concentrated in a vacuum evaporator. The concentrated extract was suspended with carboxymethylcellulose (CMC) $0.5 \%$ and separated to the concentration of $90 \mathrm{mg} / \mathrm{kg}$ and $115 \mathrm{mg} / \mathrm{kg}$ of body weight as described in previous research (Widyastuti et al., 2020).

\section{Experimental Design}

This study was designed for four weeks, randomized allocation, placebo-controlled, parallel-group experimental trial to evaluate the effect of ethanolic extract cogon grass roots (CGG) in in-vivo mice preimplantation embryo development (Mus musculus albinus). The study protocol was approved by Ethics Review Committee Faculty of Medicine, Universitas Padjadjaran (No.1326/UN6.KEP/EC/2018)

\section{Animals Subject}

A virgin female mice DDY (Bio Farma, Bandung, Indonesia), aged eight weeks, with normal estrus cycle (average 4-6 days of proestrus, estrus, metestrus, and diestrus phases) weighing about 25-40 g were selected (Widyastuti et al., 2020). Mice were acclimatized for seven days before the experiment. Animals were housed in plastic cages $(50 \mathrm{~cm}$ long x $40 \mathrm{~cm} \times 15 \mathrm{~cm}$ high, 5 mice each cage) under the 12/12 light-dark cycle and were fed with standard food and tap water.

The 60 female mice were randomly grouped into three groups, each group consisted of 20 female mice. Mice in Group A received 0.5\% carboxymethylcellulose (CMC) by gavage, whereas mice in group $\mathrm{B}$ and $\mathrm{C}$ received $90 \mathrm{mg} /$ $\mathrm{kg}$ body weight (BW) and $115 \mathrm{mg} / \mathrm{kg}$ BW of CGG per day, respectively.

\section{Superovulation}

Animals were stimulated after 20 days of oral administration of CGG with 5 IU PMSG and after 48 hours followed by 5 IU hCG intraperitoneal (IP) injection. To evaluate the number of ovulated and fertilized oocytes, development of in-vivo embryo preimplantation, the stimulated female mice were mated with male mice with a ratio of $2: 1$ immediately after hCG injection (Luo et al., 2011).

\section{Evaluation of Mating Rates}

The next morning after 12 hours of hCG injection, the animals were checked for the appearance of the vaginal plug to examine the mating rate (Behringer et al., 2016; Pijnenborg, 2015). The following reproductive parameter was then calculated based on the previous study (Shah et al., 2016) with the formula: \% of mating rate $=[($ number mated $) \times$ (total female mice in each group $\left.)^{-1}\right]$ x $100 \%$.

The animals were weighed and sacrificed with anesthetic isoflurane with drap jar method before cervical dislocation (Flecknell, 2009a, Flecknell, 2009b). The female mice were sacrificed several days periodically according to the development of mice embryos during the preimplantation stage.

\section{Evaluation of The Oocytes, Fertilization Rates, Cleavage, and Blastocyst Embryos}

The oocytes and the fertilized oocytes were collected from the oviducts (tuba fallopian) and uterine, while the preimplantation embryos collected form oviduct for cornua uterine. The oviducts and cornua uterine were isolated and cleared from adhering tissues by flushing the oviducts with phosphate buffer saline (PBS) solution (Schatten, 2004). The cells were collected in petri-dish and observed under a stereomicroscope to determine the number of cells produced. Oocytes and fertilized oocytes were observed 14 hours post hCG injection. The cleavage embryos were collected 38-40 hours post hCG injection. Blastocyst embryos were collected 114-116 hours after hCG injection.

\section{Statistical Analysis}

All the values were expressed as mean. The degree of significance was set at $p<0.05$ relation to control and standard using Kruskal Wallis. All the analyses were carried out using GraphPad software $7^{\text {th }}$ version.

\section{RESULTS AND DISCUSSION}

The developmental of mouse embryo in vivo illustrated in Figure 1. The administration of the CGG extract for 20 days significantly decreased the mating rate in Group C compared to group B and control $(\mathrm{p}<0.05)$. Whereas in Group B showed no significant difference compared to control (Figure 2).

The number of ovulated oocytes was significantly reduced in groups $\mathrm{B}$ and $\mathrm{C}$ 


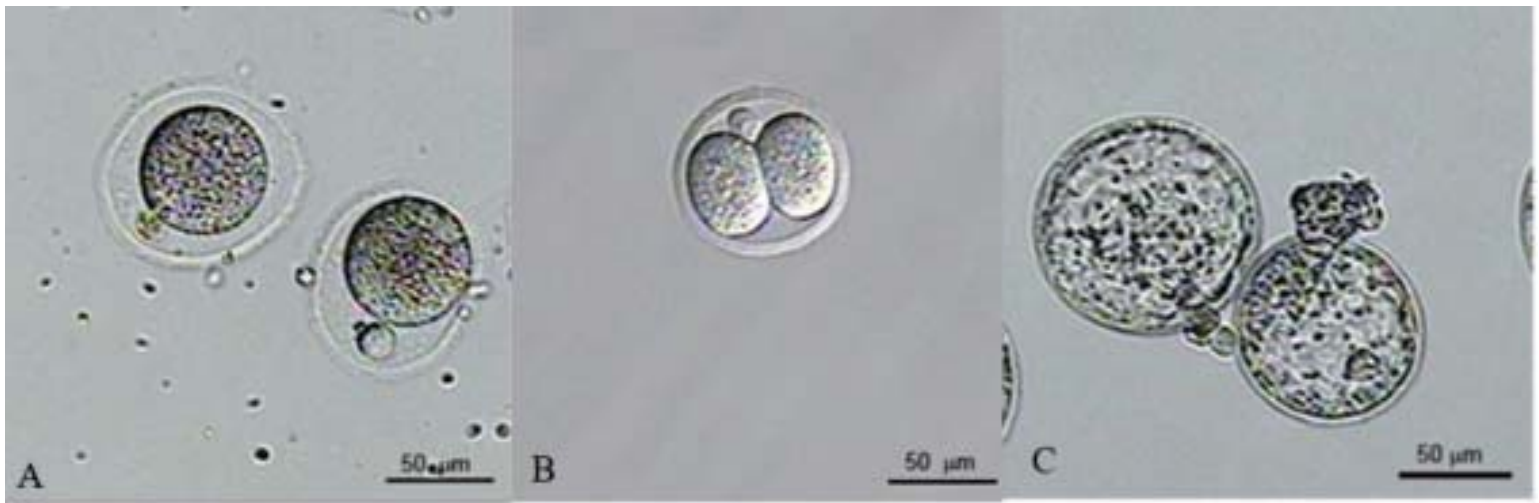

Figure 1.Developmental of mouse embryos in vivo. (A) mature oocytes, (B) cleavage embyros, (C) Blastocyst embryos

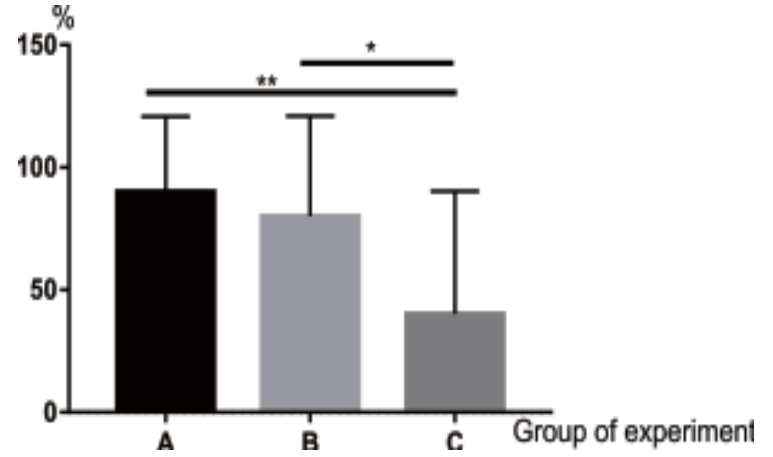

Figure 2. The effect of 20 days oral administration Imperata cylindrica $\mathrm{L}$ roots extract on mating rate of female mice. (A) control group, (B) $90 \mathrm{mg} / \mathrm{kg} \mathrm{b.w},(\mathrm{C}) 115 \mathrm{mg} / \mathrm{kg}$ b.w.

consecutively compared to control (Figure 3a, $\mathrm{p}<0.05)$. Furthermore, the development of invivo embryos also decreased in dose depending pattern. Merely in all groups, most of the oocytes undergone fertilization (Figure 3b). Looking at the embryo development, Group B and Group C showed about a half and one-third reduction of cleavage rates, respectively compared to control (Figure $3 c, p<0.05$ ). Seven from nine of cleavage cells progress to blastocyst from the control group, whereas in group $\mathrm{B}$ and $\mathrm{C}$ only half of the cleavage develops into a blastocyst (Figure $3 \mathrm{~d}$ ). Overall results showed a decreasing tendency of in-vivo mice preimplantation embryo development in treatment groups compared to control with the highest reduction in group $\mathrm{C}$.

In the present study, I. cylindrica L. root ethanolic reduce mice fertility effect by decreasing their mating rates, the number of oocytes produced, and in-vivo development preimplantation embryos. The decreased mating rate may be induced by the change of the treatment group's estrus phase duration. The previous study reported that the oral administration of $I$. cylindrica L. induced prolonged diestrus phase (Robianto et al., 2018). In the diestrus phase, corpus lutea secretes progesterone to prepare the endometrium for implantation and estrogen produced by granulose cells to thicken the endometrial lining. If this stage is prolonged, estrogen could not attain the maximum level which leads to Luteinizing Hormone ( $\mathrm{LH}$ ) and Follicle Stimulating Hormone (FSH) surge thus, no ovulation occurred. Duration of estrus phase also shortened, which implies decreased chance time for mating (Yakubu et al., 2010).

The results showed that the gavage of $I$. cylindrica $\mathrm{L}$. decreased the number of oocytes and in-vivo embryo development. The disturbance may cause a decreased number of ovulated oocytes in folliculogenesis. The previous study reported that the short term gavage $I$. cylindrica L. reduces FSH serum level, increases corpus luteum number, and prolonged diestrus phase, thus impair folliculogenesis (Widyastuti et al., 2020).

The lower number of cleavage and blastocyst strongly correlated with the decrease of oocytes number and fertilized oocytes in a group of treatment compared to control. The decrease in embryo development might be due to antiproliferative, cytotoxic, and antiimplantation effects of flavonoids, alkaloids, and saponins. Due to I. cylindrica L. root ethanolic extract that was given for several days to female mice, they might not be able to eliminate the extract's active compounds in blood vessels. Therefore, it can affect the development of the embryos by its 

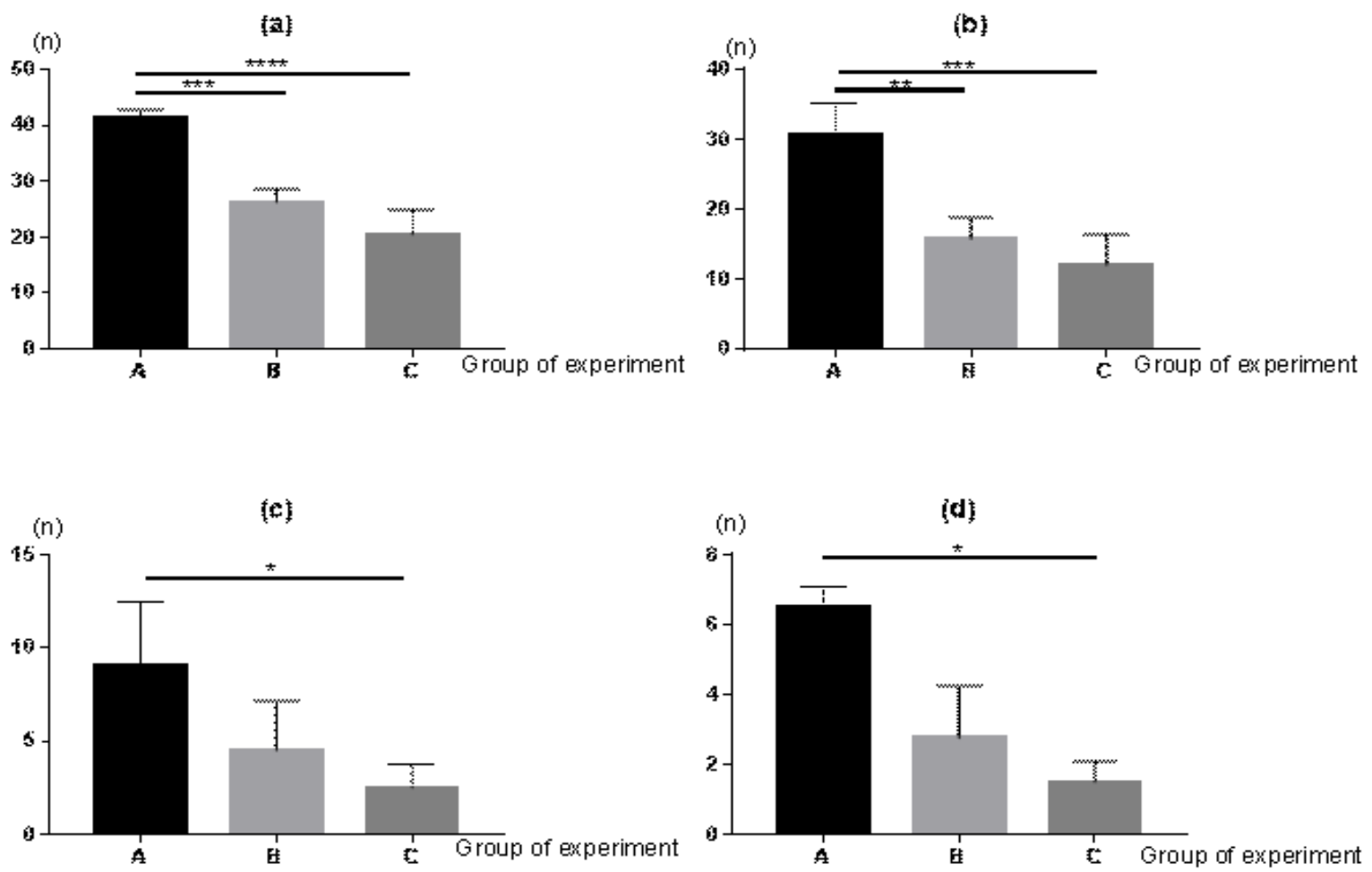

Figure 3.The effect of 20 days oral administration Imperata cylindrica L roots extract on the mating rate of female mice; (a) The number ovulated oocytes (b) fertilized oocytes, (c) cleavage embryos, (d) blastocyst embryos. (A) control group, (B) $90 \mathrm{mg} / \mathrm{kg}$ b.w, (C) 115 $\mathrm{mg} / \mathrm{kg}$ b.w.

active compounds, and those embryos could not reach preimplantation development until the blastula phase (Widiana and Sumarmin, 2016).

Phytochemical studies in the roots of $I$. cylindrica var. major resulted mostly phenolic compounds such as flavonoids, simple phenols, phenolic acids, coumarins, lignans, terpenoids, tannins, saponins, alkaloids (Liu et al., 2012). Flavonoids, coumarins, lignans, terpenoids, saponins, and alkaloids have phytoestrogens effects that can mimic or interfere with the action of estrogens (Grippo et al., 2007; Mbemya et al., 2017). Phytoestrogen is a natural compound contained in plants that able to bind estrogen receptor and stimulate estrogendependent transcription. Although the activity is low (1/100 than natural estrogen, E2), their utilization exhibits significant effect in gonadal organs (Ye et al., 2016; Puranik et al., 2019). Alkaloid inhibits implantation and has an abortifacient effect by increasing uterine contraction. They competitively bind estrogen receptor then inhibit LH and FSH secretion. In addition, flavonoid act as cell cycle modulator which can inhibit cell proliferation induce apoptosis. This implies that the failure of decidua formation leads to the failure of blastocyst implantation (Yakubu et al., 2010). Saponins as steroid compounds harm animal reproduction known as an abortifacient, zygote development inhibition, and antiimplantation (Francis et al., 2002). Saponins have cytotoxic effects specifically in developing cell example in the process of oogenesis. These estrogenic effects from I. cylindrica L. can interfere ovulation process, fertilization, and the development of the embryos.

This study's result is consistent with previous findings of several plants that contain phytoestrogen properties with anti-implantation and antifertility effects. Rat treated with Anethum graveolens L. or dill leaf and seed extract showed increased progesterone level, prolonged diestrus phase, and the disturbing regular estrous cycle. The mating was delayed and the number of live fetuses decreased compared to the control group (Monsefi, 2014). The consumption of high dose Zingiber officinale (ginger) decreases estrus cycle duration, implantation sites, and the number of live 
fetuses. The progesterone production was impaired by disrupting corpus luteum development that needs in early pregnancy (Elmazoudy 2018). Administration of Ginkgo biloba to female rats induces vaginal bleeding, abortion, preimplantation and postimplantation loss, and the increasing number of non-viable fetuses (Elmazoudy, 2012).

\section{CONCLUSION}

To conclude, gavage of $I$. cylindrica $\mathrm{L}$ ethanolic root extract could affect mice mating rate, the development of mice embryo's cells, reduce conception and pregnancy.

\section{SUGGESTION}

Further study is required to know the minimal dose of CGG extract that causes impairment of postimplantation embryo development, abortifacient rate, and teratogenic effect towards the fetus.

\section{ACKNOWLEDGMENT}

This research was funded by the University Grant for Basic Research of Indonesian Ministry of Research, Technology, and Higher Education fiscal year $2020 \mathrm{SK}$ B/22-6/UN 14.4.A/PT.01.05/ 2020 .

\section{REFERENCES}

Agarwal A, Allan JJ. 2010. Antifertility effects of herbs: Need for responsible reporting. $J$ Ayurveda Integr Med 1(2): 129-131.

Bala K, Arya M, Katare DP. 2014. Herbal contraceptive: an overview. World J Pharm Pharm Sci 3(8): 305-1326..

Behringer R, Gertsenstein M, Nagy KV, Nagy A. 2016. Selecting female mice in estrus and checking plugs. Cold Spring Harb. Protoc. doi:10.1101/pdb.prot092387.

Byers SL, Wiles MV, Dunn SL, Taft RA. 2012. Mouse estrous cycle identification tool and images. PLoS One 7: e35538.
Chantong B, Kampera T, Sirimanapong W, Wongtongtair S, Hutamekalin P, Meksuriyen D. 2008. Antioxidant activity and cytotoxicity of plants commonly used in veterinary medicine. Acta Hortic 786: 91-98.

Dhianawaty D. 2015. Kandungan Total Polifenol dan Aktivitas Antioksidan dari Ekstrak Metanol Akar Imperata cylindrica (L) Beauv.(Alang-alang). Majalah Kedokteran Bandung 47(1): 60-64.

ElMazoudy RH, Attia AA. 2012. Efficacy of Ginkgo biloba on vaginal estrous and ovarian histological alterations for evaluating anti implantation and abortifacient potentials in albino female mice. Birth Defects Research Part B: Developmental and Reproductive Toxicology 95(6): 444-459.

ElMazoudy RH, Attia AA. 2018. Ginger causes subfertility and abortifacient in mice by targeting both estrous cycle and blastocyst implantation without teratogenesis. Phytomedicine 50(15): 300-308.

Flecknell PA. 2009a. Anaesthesia. In : Flecknell, PA ( $3^{\text {rd }}$ Ed). Laboratory Animal Anaesthesia. San Diego. Academic Press. Pp. 19-78.

Flecknell PA. 2009b. Anaesthetic Management. In: Flecknell PA. ( $3^{\text {rd }}$ Ed). Laboratory Animal Anaesthesia. San Diego. Academic Press. Pp. 79-108

Francis G, Kerem Z, Makkar HP, Becker K. 2002. The biological action of saponins in animal systems: A review. Br J Nutr 88(6): 587-605.

Grippo AA, Capps K, Rougeau B, Gurley BJ. 2007. Analysis of flavonoid phytoestrogens in botanical and ephedra-containing dietary supplements. Ann Pharmacother 41(9): 1375-1382.

Hull T, Mosley W. 2009. Revitalization of Family Planning in Indonesia. Jakarta. Bappenas, BKKBN and UNFPA. Pp. 13-22.

Karra M, Canning D, Hu J, Ali M, Lissner C. 2016. Community based financing of family planning in developing countries: A systematic review. Studies in family planning 47(4): 325-339.

Liu X, Zhang B, Chou G, Yang L, Wang Z. 2012. Chemical constituents from Imperata cylindrica. Zhongguo Zhong Yao Za Zhi 37(15): 2296-2300. 
Lubis A, Widyastuti R, Robianto S, Priscilla M, Syamsunarno MRAA. 2018. Old Mice Epididymal Sperm Quality After Short Term Gavage of Cogon Grass Root Ethanol Extract. Majalah Kedokteran Bandung 50(2): 126.

Luo C, Zuñiga J, Edison E, Palla S, Dong W, Parker-Thornburg J. 2011. Superovulation strategies for 6 commonly used mouse strains. J Am Assoc Lab Anim Sci 50(4): 471-478.

Monsefi M, Lohrasbi P, Abpaikar Z and Bakhtiari S. 2014. Anti-implantation and antifertility potentials of Anethum graveolens L. extracts in rats. Toxicological \& Environmental Chemistry 96(9): 14021413.

Mbemya GT, Vieira LA, Canafistula FG, Pessoa ODL, Rodrigues APR. 2017. Reports on in vivo and in vitro contribution of medicinal plants to improve the female reproductive function. Reprodução \& Climatério 32(2): 109-119.

Pijnenborg R. 2015. The guide to investigation of mouse pregnancy. Placenta 36(2): 253-254.

Puranik NV, Srivastava P, Bhatt G, Mary DJSJ, Limaye AM, Sivaraman J. 2019. Determination and analysis of agonist and antagonist potential of naturally occurring flavonoids for estrogen receptor (ERá) by various parameters and molecular modelling approach. Scientific Reports 9(1): 1-11.

Robianto S, Syamsunarno MRAA, Lubis A, Priscilia M, Anggraeni N, Ghozali M, Ritonga M, Widyastuti R. 2019. The effect of ethanol extract of Cogon grass root (Imperata cylindrica) to estrus cycle and metabolite profile in female mice. Jurnal Veteriner 20(2): 196-201.

Schatten H. 2004. Germ Cell Protocols: Sperm and Oocyte Analysis. Berlin. Springer Science and Business Media. pp 235-253

Shah M, Singh R, Shah R, Kakar S. 2016. An overview of the current methodologies used for evaluation of antifertility agents. Asian Pacific Journal of Reproduction 5(3): 175178.
Shukla A, Jamwal, R. 2017. Adverse effect of combined oral contraceptive pills. Asian J Pharma \& Clin Res10(1): 17-21.

Shweta G, Chetna R, Jinkal S, Nancy S, Hitesh J. 2011. Herbal plants used as contraceptives. Int J Curr Pharm Rev Res 2(1): 47-53.

Widiana R, Sumarmin R. 2016. Efek toksik dan teratogenik ekstrak brotowali (Tinospora crispa l.) terhadap sistem reproduksi dan embrio mencit (Mus musculus l. Swiss webster). Jurnal BioConcetta 2(1): 1-11,

Widyastuti R, Sudiman J, Tyagita T, Syamsunarno MRAA, Sumarsono SH. 2018. Oral administration of cogon grass ( Imperata cylindrica L. ) root ethanol- extract causes mouse epididymal sperm abnormality. $J$ Veteriner 19(3): 1-6.

Widyastuti R, Prastowo S, Sumarsono SH. Lubis A, Hartady T, Syamsunarno MRAA, Sudiman J. 2020. Deleterious effect of shortterm gavage of an ethanol extract of cogon grass (Imperata cylindrica L.) roots on testis and epididymal sperm quality. Veterinary World 13(7): 1311-1318

Widyastuti R, Boediono A, Syamsunarno MRAA, Ghozali M, Ritonga MA, Lubis A, Robianto S, Sudiman J. 2020. Effect of short-term gavage of ethanolic extract of cogon grass (Imperata cylindrica L) root on the ovarian activity and estrus behavior of female mice. Asian Pacific Journal of Reproduction 9(2): 70 .

Yakubu MT, Adeshina AO, Oladiji AT, Akanji MA, Oloyede O, Jimoh GA, Olatinwo AWO, Afolayan AJ. 2010. Abortifacient potential of aqueous extract of Senna alata leaves in rats. Journal of Reproduction and Contraception 21(3): 163-177.

Ye H, Ng HW, Sakkiah S, Ge W, Perkins R., Tong W, Hong H. 2016. Pathway analysis revealed potential diverse health impacts of flavonoids that bind estrogen receptors. International Journal of Environmental Research and Public Health 13(4): 373. 